\title{
Re-evaluation of pneumonia requiring admission to an intensive care unit: a prospective study
}

\author{
Nabil S Dahmash, Mohammad N H Chowdhury
}

\begin{abstract}
Background - Appropriate treatment of severe community and hospital acquired pneumonias requiring admission to a medical intensive care unit depends on knowledge of the likely aetiological agents in any community. Little is known about the pattern and outcome of patients with such pneumonias in Saudi Arabia.

Methods - In a prospective study 113 patients with pneumonia were investigated in the medical intensive care unit at King Khalid University Hospital, Riyadh, Saudi Arabia between September 1991 and December 1992. The diagnosis was established by microscopy and culture of sputum, blood culture, or serological examination. A standard proforma was used to collect demographic, clinical, and laboratory data.
\end{abstract}

Results - A microbiological diagnosis was made in $80 \%$ of the cases with a single pathogen accounting for $69 \%$ of the isolates and multiple pathogens for $11 \%$. Pseudomonas aeruginosa was the most common infecting agent $(16 \%)$, followed by Streptococcus pneumoniae (12\%), Staphylococcus aureus (9\%), and Mycobacterium tuberculosis (8\%). Pneumonia due to Legionella pneumophilia was diagnosed in three patients and infection due to Mycoplasma pneumoniae in two. These five cases were identified by serological examination. Gram negative rods were the predominant pathogens in both community and hospital acquired pneumonia. The aetiology of pneumonia was not identified in $20 \%$ of cases. The overall mortality was $37 \%$. Patients with hospital acquired pneumonia had a higher mortality than those with a community acquired pneumonia. Similarly, a high mortality was found in patients who had a serious underlying disease, abnormal mental state, diastolic blood pressure $<60 \mathrm{mmHg}$, blood urea $>7 \mathrm{mmol} / 1$, abnormal liver function tests, serum albumin $<30 \mathrm{~g} / 1$, those who required mechanical ventilatory support, and those with APACHE II scores $>20$.

Conclusions - This study highlights two major findings which differ from previous reports on the aetiology of pneumonia. Firstly, Gram negative rods were the predominant pathogens in community acquired pneumonia and secondly, $M$ tuberculosis was an important cause of pneumonia in these patients, indicating that tuberculous pneumonia should be considered in the differential diagnosis of pneumonia in Saudi Arabia.

(Thorax 1994;49:71-76)

Community and hospital acquired pneumonias are still a significant cause of morbidity and mortality ${ }^{1-4}$ and up to $2 \%$ of patients discharged from acute hospitals have pneumonia as a primary diagnosis. ${ }^{5}$ The pathogenesis is complex involving altered host defences, decreased mechanical bacterial clearance, ascending bacterial colonisation of the pharynx, and tracheal aspiration..$^{5-8}$ The incidence of pneumonia may vary between geographical areas and even between hospitals. The prognosis can vary according to the host factors and hospital service. Several authors have reported fatality rates of between $30 \%$ and $70 \%$ for pneumonia requiring admission to intensive care units. ${ }^{1-3}$

The aim of this study was to investigate the incidence, aetiology, risk factors, and mortality of pneumonia requiring admission in the medical intensive care unit at King Khalid University Hospital, Riyadh, Saudi Arabia.

\section{Methods}

A total of 113 patients with pneumonia were admitted to the intensive care unit between September 1991 and December 1992. Patients included in the study were those admitted directly to the unit and those transferred from medical wards because of the severity of their illness. Criteria for admission to the unit included progressive hypoxaemia, changes in mental state including confusion or coma, hypotension, inability to clear bronchial secretions, and respiratory failure requiring intermittent positive pressure ventilation. Severity of illness was determined for all patients by the acute physiology and health care evaluation (APACHE II) scoring system. ${ }^{9}$ The presumptive diagnosis of pneumonia was made on clinical grounds which included pyrexia, cough and purulent sputum, crackles and bronchial breathing, an increase in white cell count, and a chest radiograph showing consolidation of a part or parts of one or both lungs. The pneumonia was classified as community acquired if the infection was present before admission, and hospital acquired if the infection developed more than 48 hours after admission. Aspiration pneumonia was diagnosed when there was a definitive history of aspiration or of changes in mental state. Patients diagnosed as having pneumonia due 
to immunocompromise included those with major host defence abnormalities, those taking immunosuppressive drugs, and those with haematological malignancy, collagen vascular disorders, and requiring high dose steroid therapy ( $>40 \mathrm{mg}$ prednisolone daily) for a long duration.

A standardised protocol was used to collect the following data: age, sex, major medical diagnosis, vital signs, pertinent laboratory data, radiographs, the result of bacteriological Gram stain and culture of sputum or blood culture, the duration of mechanical ventilation, and duration of stay in the intensive care unit. Criteria for the diagnosis of hypotension, leucopenia, thrombocytopenia, and disseminated intravascular coagulation were those published previously. ${ }^{1}{ }^{10} 11$

Diagnoses regarding infective aetiology were made on microscopy or culture of sputum, blood culture, or serology. Tracheal aspirates were collected from 70 patients (35 with community acquired and 35 with hospital acquired pneumonia) immediately following intubation. Sputum specimens were considered significant only if a predominant organism was present on Gram stain in the presence of numerous pus cells without excessive squamous epithelial cells $(<10 /$ low power field), and if a pathogen was isolated in a heavy growth on culture. In addition, anaerobic cultures were performed routinely for all bronchoscopy specimens. All investigations were performed immediately on admission to the unit. The diagnosis of pneumonia for both community acquired and hospital acquired infections was confirmed in all cases in the intensive care unit based on the results of these investigations.

At least two sets of blood cultures were collected routinely from each patient according to the methods described previously. ${ }^{11}$ Antibiotic susceptibility testing was carried out by disc diffusion using a rotating Stoke's technique. ${ }^{12}$

Flexible fibreoptic bronchoscopy and bronchoalveolar lavage were performed following intubation if no diagnosis was obtained by other investigations, including sputum microscopy and culture, within 48 hours of admission to the unit in patients who were immunocompromised or who failed to respond to the initial antibiotic regimen. Protected specimen brushing was performed in nine immunocompromised patients with pneumonia. A colony count of $>10^{3} \mathrm{cfu} / \mathrm{ml}$ was considered significant. ${ }^{13}$ Legionella, mycoplasma, chlamydia, and viral serology were performed in patients with clinical presentations suggestive of atypical pneumonia which included non-productive cough, low grade fever, normal leucocyte counts, or many pus cells but no organisms on sputum Gram stain. Serological examination was also performed in patients where routine examination did not reveal the aetiology. A fourfold rise in antibody titre on paired samples was considered significant. Pneumococcal capsular antigens were not determined.

All patients were started on empirical antibiotic treatment once pneumonia was suspected.
The antibiotic regimens given to each group of patients were almost the same as follows. For patients with community acquired pneumonia intravenous penicillin or ampicillin was administered if Gram stain, clinical features, or both, were suggestive of pneumococcal pneumonia. Similarly, intravenous erythromycin was given to patients who were suspected of having atypical pneumonia. For patients with hospital acquired pneumonia penicillin and ceftazidime were used. Metronidazole was added when anaerobic infections were suspected - that is, aspiration pneumonia, patients with coma, seizures, and vomiting. For immunocompromised patients such as those with leukaemia a combination of ceftazidime, amikacin, and vancomycin was given. For patients with a high risk of acquiring pneumonias due to Gram negative rods such as those with bronchiectasis or diabetes mellitus, penicillin and ceftazidime were administered. Empirical antibiotic treatment was adjusted as soon as the sensitivities of the infecting organisms were known. Treatment was considered inappropriate if the organism was resistant on in vitro testing or an inappropriate antibiotic had been given. In addition to antibiotic treatment, hypotensive patients received fluid in the form of crystalloids or colloids. ${ }^{11}$ Blood transfusion was given if the haemoglobin level was $<11 \mathrm{~g} / \mathrm{dl}$. Inotropic agents (dopamine or dobutamine) were added if there was no response to fluid therapy. A Swan-Ganz catheter was inserted in 10 patients with a transient response. ${ }^{11}$

\section{STATISTICAL ANALYSIS}

For comparison among groups the $\chi^{2}$ test was used, $\mathrm{p}<0.05$ being considered significant.

\section{Results}

The 113 patients included 63 with community acquired pneumonia and 50 with hospital acquired infection. Their ages ranged from 12 to 100 (mean 49 ) years, with $53(47 \%$ ) below 50 years of age and $31(27 \%)$ between 50 and 69 years. The male to female ratio was 1.3:1. There was no significant difference in mortality between the sexes but it was higher in patients over 50 years $(p<0.02)$.

Of 63 patients with community acquired pneumonia 56 were admitted directly to the intensive care unit from the accident and emergency department. None received any antibiotics before admission. The diagnosis of pneumonia in these patients was confirmed by examination of the sputum samples, tracheal aspirates, blood cultures, or serology on specimens collected immediately on admission to the unit. The remaining seven patients were admitted initially to medical wards and transferred to the unit after 12-24 hours. All were treated with antibiotics in the medical wards. One patient received penicillin and ceftriaxone, three ampicillin, and three cefuroxime. Three of the seven patients had no underlying disease; two had diabetes mellitus, one ethanol abuse, and one bronchiectasis. The final cause 
Table 1 Underlying diseases associated with pneumonia

\begin{tabular}{|c|c|c|c|c|c|c|}
\hline \multirow[t]{2}{*}{ Disease } & \multicolumn{2}{|l|}{$C A P$} & \multicolumn{2}{|l|}{$H A P$} & \multirow[t]{2}{*}{ Total no. $(\%)$} & \multirow[t]{2}{*}{ No. dead $(\%)$} \\
\hline & Total & Dead & Total & Dead & & \\
\hline $\begin{array}{l}\text { Respiratory } \\
\text { Bronchitis/emphysema } \\
\text { Asthma } \\
\text { Bronchiectasis } \\
\text { Interstitial lung disease }\end{array}$ & $\begin{array}{l}5 \\
1 \\
2\end{array}$ & $\begin{array}{l}1 \\
1\end{array}$ & $\begin{array}{l}4 \\
3 \\
7 \\
2\end{array}$ & $\begin{array}{l}2 \\
1 \\
1\end{array}$ & $\begin{array}{l}24(21) \\
9(8) \\
4(4) \\
9(8) \\
2(2)\end{array}$ & $\begin{array}{l}6(14) \\
3(7) \\
1(1) \\
1(2) \\
1(2)\end{array}$ \\
\hline $\begin{array}{l}\text { Non-respiratory } \\
\text { Cardiovascular } \\
\text { Neurological } \\
\text { Diabetes mellitus } \\
\text { Gastrointestinal } \\
\text { Renal } \\
\text { Collagen vascular disease } \\
\text { Neoplastic* } \\
\text { Psychiatric } \\
\text { Osteomyelitis } \\
\text { Carbon monoxide poisoning } \\
\text { AIDS } \\
\text { Agammaglobulinaemia }\end{array}$ & $\begin{array}{r}2 \\
4 \\
10 \\
1 \\
4 \\
5 \\
7 \\
4 \\
2 \\
1 \\
1\end{array}$ & $\begin{array}{l}3 \\
3 \\
1 \\
2 \\
2 \\
4 \\
1 \\
\end{array}$ & $\begin{array}{l}2 \\
9 \\
3 \\
5 \\
1 \\
4 \\
9 \\
1\end{array}$ & $\begin{array}{l}1 \\
4 \\
3 \\
3 \\
1 \\
1 \\
3\end{array}$ & $\begin{array}{l}75(66) \\
4(4) \\
13(12) \\
13(12) \\
6(5) \\
5(4) \\
9(8) \\
16(14) \\
4(4) \\
1(1) \\
2(2) \\
1(1) \\
1(1)\end{array}$ & $\begin{array}{l}34(81) \\
1(2) \\
7(17) \\
6(14) \\
4(10) \\
3(7) \\
3(7) \\
7(17) \\
1(2) \\
0(0) \\
0(0) \\
1(2) \\
1(2)\end{array}$ \\
\hline None & 14 & 2 & & & $14(12)$ & $2(5)$ \\
\hline Total & 63 & 22 & 50 & 20 & 113 & 42 \\
\hline
\end{tabular}

$\mathrm{CAP}=$ community acquired pneumonia; $\mathrm{HAP}=$ hospital acquired pneumonia

* Includes seven carcinomas, nine leukaemias and lymphomas.

of the pneumonia in these patients was as follows: one Mycoplasma pneumoniae, two Legionella pneumophilia, two Pseudomonas aeruginosa, and one Escherichia coli. No aetiology was found in one case. Pneumonia in these patients was diagnosed in the unit on transfer from medical wards by examination of sputum samples and other specimens.

Table 1 shows the various underlying diseases in the patients, showing that only 14 of $113(12 \%)$ were previously healthy. There were 42 deaths, giving an overall mortality of $37 \%$. Table 2 shows the clinical and laboratory data of these patients. The rate of mortality

Table 2 Clinical and laboratory features of patients with pneumonia

\begin{tabular}{|c|c|c|c|}
\hline Variable & Total no. $(\%)$ & No. dead (\%) & $p$ \\
\hline \multicolumn{4}{|l|}{ Mental status } \\
\hline $\begin{array}{l}\text { Normal } \\
\text { Abnormal }\end{array}$ & $\begin{array}{l}57(50) \\
56(50)\end{array}$ & $\begin{array}{l}13(23) \\
29(52)\end{array}$ & $<0.005$ \\
\hline \multicolumn{4}{|l|}{ Blood pressure } \\
\hline $\begin{array}{l}\text { Diastolic BP }>60 \mathrm{~mm} \mathrm{Hg} \\
\text { Diastolic BP }<60 \mathrm{~mm} \mathrm{Hg}\end{array}$ & $\begin{array}{l}51(45) \\
62(55)\end{array}$ & $\begin{array}{l}12(24) \\
30(48)\end{array}$ & $<0.01$ \\
\hline \multicolumn{4}{|l|}{ Immune status } \\
\hline $\begin{array}{l}\text { Immunocompromised* } \\
\text { Normal }\end{array}$ & $\begin{array}{l}24(21) \\
89(79)\end{array}$ & $\begin{array}{l}11(46) \\
31(35)\end{array}$ & NS \\
\hline \multicolumn{4}{|l|}{ Mechanical ventilation } \\
\hline $\begin{array}{l}\text { Yes } \\
\text { No }\end{array}$ & $\begin{array}{l}70(62) \\
43(38)\end{array}$ & $\begin{array}{c}39(56) \\
3(7)\end{array}$ & $<0.001$ \\
\hline \multicolumn{4}{|l|}{ Leucocyte count $\left(\times 10^{9} / 1\right)$} \\
\hline $\begin{array}{l}>11 \cdot 0 \\
4 \cdot 0-11 \cdot 0 \\
<4 \cdot 0\end{array}$ & $\begin{array}{l}78(69) \\
25(22) \\
10(9)\end{array}$ & $\begin{array}{r}30(39) \\
6(24) \\
6(60)\end{array}$ & NS \\
\hline \multicolumn{4}{|l|}{ Granulocyte count $\left(\times 10^{9} / 1\right)$} \\
\hline $\begin{array}{l}>0.5 \\
<0.5\end{array}$ & $\begin{array}{c}105(93) \\
8(7)\end{array}$ & $\begin{array}{r}37(35) \\
5(63)\end{array}$ & NS \\
\hline \multicolumn{4}{|l|}{ Coagulation disorder } \\
\hline $\begin{array}{l}\text { DIC/thrombocytopenia } \\
\text { None }\end{array}$ & $\begin{array}{l}30(26) \\
83(74)\end{array}$ & $\begin{array}{l}16(53) \\
26(31)\end{array}$ & NS \\
\hline \multicolumn{4}{|l|}{ Sodium } \\
\hline $\begin{array}{l}<130 \mathrm{mmol} / 1 \\
>130 \mathrm{mmol} / 1\end{array}$ & $\begin{array}{l}15(13) \\
98(88)\end{array}$ & $\begin{array}{r}7(47) \\
35(36)\end{array}$ & NS \\
\hline \multicolumn{4}{|l|}{ Urea } \\
\hline $\begin{array}{l}<7 \mathrm{mmol} / 1 \\
>7 \mathrm{mmol} / \mathrm{l}\end{array}$ & $\begin{array}{l}80(71) \\
33(29)\end{array}$ & $\begin{array}{l}20(25) \\
22(67)\end{array}$ & $<0.001$ \\
\hline \multicolumn{4}{|l|}{ Liver function } \\
\hline $\begin{array}{l}\text { Abnormal } \\
\text { Normal }\end{array}$ & $\begin{array}{l}29(26) \\
84(74)\end{array}$ & $\begin{array}{l}17(59) \\
25(30)\end{array}$ & $<0.01$ \\
\hline $\begin{array}{l}\text { Albumin }(\mathrm{g} / \mathrm{l}) \\
\quad<30 \\
>30\end{array}$ & $\begin{array}{l}70(62) \\
43(38)\end{array}$ & $\begin{array}{r}35(50) \\
7(16)\end{array}$ & $<0.01$ \\
\hline $\begin{array}{l}\mathrm{PaO}_{2} \\
<50 \mathrm{~mm} \mathrm{Hg}(<8 \mathrm{kPa}) \\
>50 \mathrm{~mm} \mathrm{Hg}(>8 \mathrm{kPa}) \\
\text { APACHE II score }\end{array}$ & $\begin{array}{l}84(74) \\
29(26)\end{array}$ & $\begin{array}{r}33(39) \\
9(31)\end{array}$ & NS \\
\hline $\begin{array}{l}\leqslant 20 \\
>20\end{array}$ & $\begin{array}{l}34(30) \\
79(70)\end{array}$ & $\begin{array}{r}4(11 \cdot 8) \\
38(48 \cdot 1)\end{array}$ & $<0.05$ \\
\hline
\end{tabular}

$\mathrm{DIC}=$ disseminated intravascular coagulation; $\mathrm{PaO}_{2}=$ arterial oxygen tension; $\mathrm{NS}=$ not signific-

* Immunocompromised due to disease, drugs, or both. was significantly higher in patients with abnormal changes in mental state, diastolic blood pressure $<60 \mathrm{~mm} \mathrm{Hg}$, urea $>7 \mathrm{mmol} / \mathrm{l}$, abnormal liver function tests, serum albumin level $<30 \mathrm{~g} / \mathrm{l}$, those requiring mechanical ventilatory support, and those with APACHE II scores $>20$.

The microbial spectrum of pneumonia is shown in table 3. Pseudomonas aeruginosa was the commonest pathogen accounting for $16 \%$ of all infections, followed by Streptococcus pneumoniae and Staphylococcus aureus. Mycobacterium tuberculosis accounted for $8 \%$. Ps aeruginosa and other enteric Gram negative rods were the predominant pathogens in both community acquired and hospital acquired pneumonias, although Str pneumoniae was the next most common pathogen encountered in community acquired pneumonia. Three patients had legionella pneumonia and two mycoplasma pneumonia. Pathogens were recovered in only three cases of aspiration pneumonia. In the immunocompromised patients Gram negative rods other than Haemophilus influenzae and $M$ tuberculosis were predominant organisms. A significantly higher mortality was observed in hospital acquired than in community acquired pneumonia $(p<0.02)$. The aetiology of pneumonia was not identified in 22 of 113 patients $(20 \%)$.

Table 4 shows the pneumonias from which multiple species were isolated. Of a total of 13 patients, 10 had two organisms, two had three organisms, and one had four organisms; seven $(54 \%)$ of these died. Although the mortality appeared to be higher than that attributable to a single agent (39\%), this was not statistically significant.

The microbiological tests performed are summarised in table 5. Sputum microscopy and culture identified pathogens in 72 of 113 $(64 \%)$ patients; positive blood culture was obtained in only $13(12 \%)$. They included Gram negative rods excluding $H$ influenzae (five cases), Str pneumoniae (four), Candida spp (three), and Staph aureus (one). Six of these patients (46\%) died; three with Candida infection, two with Gram negative rods, and 
Table 3 Organisms isolated from patients with pneumonia

\begin{tabular}{|c|c|c|c|c|c|c|}
\hline \multirow[t]{2}{*}{ Microorganism } & \multirow[t]{2}{*}{ Total no. (\%) } & \multicolumn{2}{|l|}{$C A P$} & \multicolumn{2}{|l|}{$H A P$} & \multirow[t]{2}{*}{ Total deaths (\%) } \\
\hline & & Total & Died & Total & Died & \\
\hline $\begin{array}{l}\text { Single pathogen: } \\
\text { Pseudomonas aeruginosa } \\
\text { Streptococcus pneumoniae } \\
\text { Staphylococcus aureus } \\
\text { Mycobacterium tuberculosis } \\
\text { Acinetobacter spp } \\
\text { Haemophilus influenzae } \\
\text { Serratia spp } \\
\text { Legionella pneumophilia } \\
\text { Klebsiella spp } \\
\text { Escherichia coli } \\
\text { Mycoplasma pneumoniae } \\
\text { Enterobacter spp } \\
\text { Proteus mirabilis } \\
\text { Xanthomonas spp } \\
\text { Aspergillus flavus } \\
\text { Herpes simplex virus (type I) }\end{array}$ & $\begin{array}{l}78(69) \\
18(16) \\
14(12) \\
10(9) \\
9(8) \\
5(5) \\
5(5) \\
3(3) \\
3(3) \\
2(2) \\
2(2) \\
2(2) \\
1(1) \\
1(1) \\
1(1) \\
1(1) \\
1(1)\end{array}$ & $\begin{array}{r}9 \\
10 \\
4 \\
9 \\
3 \\
3 \\
0 \\
3 \\
1 \\
2 \\
2 \\
0 \\
1 \\
0 \\
0 \\
1\end{array}$ & $\begin{array}{l}2 \\
1 \\
2 \\
5 \\
2 \\
1 \\
0 \\
1 \\
1 \\
1 \\
1 \\
0 \\
0 \\
0 \\
0 \\
1\end{array}$ & $\begin{array}{l}9 \\
4 \\
6 \\
0 \\
2 \\
2 \\
3 \\
0 \\
1 \\
0 \\
0 \\
1 \\
0 \\
1 \\
1 \\
0\end{array}$ & $\begin{array}{l}4 \\
1 \\
1 \\
0 \\
1 \\
1 \\
2 \\
0 \\
0 \\
0 \\
0 \\
0 \\
0 \\
1 \\
1 \\
0\end{array}$ & $\begin{array}{c}30(39) \\
6 \\
2 \\
3 \\
5 \\
3 \\
2 \\
2 \\
1 \\
1 \\
1 \\
1 \\
0 \\
0 \\
1 \\
1 \\
1\end{array}$ \\
\hline Polymicrobial & $13(11)$ & 1 & 1 & 12 & 6 & $7(54)$ \\
\hline Aetiology unknown & $22(20)$ & 14 & 3 & 8 & 2 & $5(23)$ \\
\hline Total (\%) & $113(100)$ & $63(55 \cdot 8 \%)$ & $22(34.9 \%)$ & $50(44 \cdot 2 \%)$ & $20(40.0 \%)$ & $42(37)$ \\
\hline
\end{tabular}

$\mathrm{CAP}=$ community acquired pneumonia; $\mathrm{HAP}=$ hospital acquired pneumonia.

one with Str pneumoniae. The mortality in patients with negative blood cultures was $29 \%$. This was not statistically significant when compared with mortality in patients having bacteraemia. Although the number of patients examined by bronchoscopy was small, pathogens were identified in $78 \%(24 / 31) . M$ tuberculosis was diagnosed in nine patients; five by bronchoalveolar lavage and four by sputum microscopy and culture. Bronchoalveolar lavage was also useful in the diagnosis of pneumonia due to cytomegalovirus, Candida spp, Pneumocystis carinii, and Aspergillus flavus in one patient with AIDS. Protected specimen brushing was performed in nine immunocompromised patients and identified pathogens in five cases where either Gram positive cocci or Gram positive rods were isolated in significant numbers which were also detected by sputum culture.

Positive serological results were obtained in

Table 4 Multiple pathogens causing pneumonia

\begin{tabular}{|c|c|c|c|}
\hline Pneumonia & Pathogens & No. of patients & No. died \\
\hline Hospital acquired & $\begin{array}{l}\text { HI, KL } \\
\text { KL, CA } \\
\text { AC, KL } \\
\text { PA, KL } \\
\text { XS, KL } \\
\text { LP, PA, EC } \\
\text { SR, PA } \\
\text { SA, AC } \\
\text { AF, XS, EC } \\
\text { PA, PM } \\
\text { AC, PA } \\
\text { SE, CA }\end{array}$ & 12 & 6 \\
\hline Community acquired & PC, AF, CMV, CA & 1 & 1 \\
\hline Total & & 13 & $7(54 \%)$ \\
\hline
\end{tabular}

$\mathrm{AC}=$ Acinetobacter $\mathrm{spp}, \mathrm{AF}=$ Aspergillus flavus, $\mathrm{CA}=$ Candida $\mathrm{spp}, \mathrm{CMV}=$ cytomegalovirus, $\mathrm{EC}=$ Enterobacter cloacae, $\mathrm{HI}=$ Haemophilus influenzae, $\mathrm{KL}=$ Klebsiella spp, $\mathrm{LP}=$ Legionella pneumophilia, $\mathrm{PA}=$ Pseudomonas aeruginosa, $\mathrm{PC}=$ Pneumocystis carinii, $\mathrm{PM}=$ Proteus mirabilis, $\mathrm{SR}=$ Serratia spp, $\mathrm{XS}=$ Xanthomonas spp.

Table 5 Diagnostic tests performed in 113 patients with pneumonia

\begin{tabular}{lclll}
\hline Test & No. tested (\%) & No. positive (\%) & CAP (\%) $(n=63)$ & HAP (\%) $(n=50)$ \\
\hline Sputum & $113(100)$ & $72(64)$ & $32(51)$ & $40(80)$ \\
Bronchoscopy & $31(28)$ & $24(78)$ & $12(19)$ & $12(24)$ \\
Blood culture & $113(100)$ & $13(12)$ & $5(10)$ & $8(16)$ \\
Serology & $28(25)$ & $5(18)$ & $5(10)$ & \\
Others* & $9(8)$ & $5(56)$ & $5(8)$ & \\
\hline
\end{tabular}

$\mathrm{CAP}=$ community acquired pneumonia; $\mathrm{HAP}=$ hospital acquired pneumonia * Includes one fine needle aspiration biopsy and eight thoracenteses. five of 28 patients $(18 \%)$ and identified three cases of legionella pneumonia and two of mycoplasma pneumonia. Herpes simplex virus type I was diagnosed by fine needle aspiration in one patient.

Forty three patients were given supplemental oxygen via Venturi or non-rebreathing masks. The remaining 70 patients (35 with community acquired and 35 with hospital acquired pneumonias) received assisted ventilation on admission to the unit. Positive end expiratory pressure was added if the patient's oxygenation remained poor on fractional inspired oxygen concentration exceeding $50 \%$. Assisted ventilation was given for two to 45 days (mean (SD) $11(10 \cdot 8)$ ) for patients with community acquired pneumonia and for six hours to 45 days (mean (SD) 13.5 (12.1)) for patients with hospital acquired disease. Duration of stay in the intensive care unit ranged from six hours to 92 days (mean (SD) $10.5(14.5)$ ) for those with community acquired pneumonia and one to 99 days (mean (SD) $14.5(18.9)$ ) for patients with hospital acquired infection.

\section{Discussion}

Little is known about the pattern of community acquired and hospital acquired pneumonias requiring admission to an intensive care unit in Saudi Arabia. ${ }^{14} 15$ In this study the most common decade in the age group of patients was $50-69$ years; $53 \%$ were over 50 years of age. This agrees with the results of a study from the UK where almost $50 \%$ of patients were aged over 61 years. ${ }^{16}$ In contrast, a study from the USA has shown that the commonest decade in 427 adult patients with pneumonia admitted to the medical wards was $40-49$ years. $^{17}$

Pneumonia is a common complication in patients with severe underlying diseases since there is decreased immunity and impaired clearance of respiratory secretions which leads to pharyngeal colonisation by pathogens that may be aspirated into the lungs. ${ }^{5}$ In agreement 
with other studies, ${ }^{18} 88 \%$ of patients in our series were found to have coexisting diseases.

We identified the agents causing pneumonia in 91 of 113 patients $(80 \%)$. By contrast, in a recent survey by the British Thoracic Society (BTS) ${ }^{1}$ on 60 patients with severe community acquired pneumonia requiring admission to an intensive care unit, $58 \%$ showed cultural evidence of pathogens or seropositivity for nonbacterial pneumonia, an incidence confirmed by other workers where an aetiology was established in $62 \%$ of cases. ${ }^{14}$ The organisms reported to be responsible for community acquired pneumonia vary. In a recent multiinstitutional study of 1378 patients admitted to the intensive care units of six hospitals, RuizSantana $e t a l^{3}$ found that Str pneumoniae (34\%) and Gram negative rods (28\%) were the predominant pathogens. Similar findings were reported in another recent intensive care unit based study where the major pathogens isolated were Str pneumoniae (33\%) and Gram negative rods $(14 \%){ }^{2}$ However, our results differ from these studies in that we isolated Gram negative rods (25\%) more frequently than Str pneumoniae (16\%). These Gram negative rods included $P s$ aeruginosa $(14 \%)$ and other Gram negative rods (11\%) excluding $H$ influenzae. In contrast to the frequent isolations of Gram negative rods in all the studies cited above, a very low rate of isolation was reported in the survey by the BTS ${ }^{1}$ who found them in only $2 \cdot 8 \%$ compared with $S t r$ pneumoniae in $31 \%$.

Several investigators have found Gram negative rods to be the most common pathogens in hospital acquired pneumonia with an incidence ranging between $40 \%$ and $87 \%,{ }^{319-21}$ while Gram positive cocci were responsible for $20 \%$ or less of the cases. ${ }^{19}$ This is consistent with our study where Ps aeruginosa and other Gram negative rods excluding $H$ influenzae were the predominant pathogens in hospital acquired pneumonia, constituting $34 \%$ of the cases, while Gram positive cocci were responsible for $20 \%$. However, Ruiz-Santana $e t a l^{3}$ found Gram negative rods in $83 \%$ of their patients but Gram positive cocci in only $14 \%$. These findings were confirmed by other authors. ${ }^{22-25}$ In agreement with other authors, ${ }^{21} 26$ $12 \%$ of our patients were bacteraemic.

The finding of pneumonia due to $M$ tuberculosis in nine $(8 \%)$ of our patients is similar to another study from Saudi Arabia where $M$ tuberculosis was responsible for $7 \cdot 1 \%$ of pneumonia in hospitalised patients. ${ }^{28}$ Pneumonia secondary to $M$ tuberculosis is relatively uncommon in western countries and rarely requires admission to the intensive care unit. $M$ tuberculosis should be considered in the differential diagnosis of pneumonia.

No pathogen was isolated in $20 \%$ of cases in our series, which is much lower than in other published series and may suggest that greater efforts were made to determine the pathogen in this seriously ill group. This is in agreement with Sorensen $e t a l^{9}$ from Sweden who established the aetiology in $81 \%$ of cases by using more intensive microbial investigations including fibreoptic bronchoscopy. However, their earlier study revealed an aetiology in 50\% of patients when intensive investigations were not performed. ${ }^{30}$

Although protected specimen brushing has been shown to be useful in diagnosing pneumonias, particularly in immunocompromised patients and nosocomial pneumonia in ventilated patients, ${ }^{31}{ }^{32}$ this was not the case in our series. Furthermore, Potgieter $e t a l^{2}$ found no pathogen in culturing brush specimens in seven patients with pneumonia that failed to respond to treatment within 72 hours. In our study bronchoscopy was valuable only in the diagnosis of tuberculous pneumonia and in one patient with AIDS. The role of invasive investigations such as bronchoscopy and percutaneous fine needle aspiration in the management of pneumonia in seriously ill patients, together with new rapid microbiological techniques such as pneumococcal and legionella antigen detection, clearly requires further assessment. ${ }^{1}$

In this study the overall mortality was high $(37 \%)$. Several factors predicted mortality including age $>50$ years, abnormal changes in mental state on admission, diastolic blood pressure $<60 \mathrm{~mm} \mathrm{Hg}$, blood urea $>7 \mathrm{mmol} / \mathrm{l}$, abnormal liver functions, serum albumin $<30 \mathrm{~g} / \mathrm{l}$, and APACHE II score $>20$. This is in agreement with other investigators. ${ }^{1} 103334$ In one study patients who required intermittent positive pressure ventilation had a mortality rate of $47 \%$ in contrast to a mortality of $5 \%$ in those not requiring ventilation. ${ }^{2}$ In our study $56 \%$ of patients who required mechanical ventilation died compared with only $7 \%$ of those managed conservatively without mechanical ventilation. In contrast to others, ${ }^{10}$ in our study a respiratory rate of $>30$ /minute, initial hypoxaemia on admission to the unit, positive blood culture, and polymicrobial aetiology were not associated with high mortality. ${ }^{110}$ However, the number of patients in our study is small and further studies are needed to substantiate these findings.

Early recognition of critically ill patients, comprehensive microbiological investigations, and selective early transfer to the intensive care unit may improve the outcome in both community acquired and hospital acquired pneumonias. Empirical and appropriate antibiotic treatment must be given immediately on hospital admission. This must be guided by knowledge of the predictable sensitivities of the probable causative organism and clinical acumen of the physician. The authors wish to express their thanks to Dr G A Oni for
statistical analysis, the nursing staff of the medical intensive statistical analysis, the nursing staff of the medical intensive
care unit at King Khalid University Hospital for their cooperation, and Ms Vergie Vicente for secretarial assistance.

1 Research Committee of the British Thoracic Society. The aetiology, management and outcome of severe community-acquired pneumonia in the intensive care unit. Respir Med 1992;86:7-13.

2 Potgieter PD, Hammond JMJ. Etiology and diagnosis of pneumonia requiring MICU admission. Chest 1992;101:199-203.

3 Ruiz-Santana $S$, Jimenez AG, Esteban A, Guerra L, Alvarez B, Corcia S, et al. ICU pneumonia: a multiinstitutional study. Crit Care Med 1987;1 5:930-2.

4 Torres A, El-Eiary M, Rodriguez-Rosin R. Nosocomial pneumonia. Current Opinion in Infectious Diseases 1993;6:163-70. 
5 Ribner B. Pneumonia: primary and nosocomial. In Dantzker DR, ed. Cardiopulmonary critical care. New York: Grune and Stratton, 1986:739-57.

6 Michael Scheld W, Mandell GL. Nosocomial pneumonia: pathogenesis and recent advances in diagnosis and therapy. Rev Infect Dis 1991;13(Suppl 9):S743-51.

7 A'Court C, Garrad CS. Nosocomial pneumonia in intensive care unit: mechanisms and significance. Thorax care unit: mo mech

8 Toews GB. Nosocomial pneumonia. Clin Chest Med 1987;8:467-79.

9 Knaus WA, Draper EA, Wagner DP, Zimmerman JE APACHE II: a severity of disease classification system. Crit Care Med 1985;13:818-29.

10 Research Committee of the British Thoracic Society. Com munity-acquired pneumonia in adults in British hospitals in 1982-1983: a survey of aetiology, mortality, prognostic factors and outcome. $Q \ngtr$ Med 1987;62:195-220.

11 Dahmash NS, Chowdhury MNH, Desouky FF. Septic shock in critically ill patients: aetiology, management and outcome. $\mathcal{F}$ Infect 1993;26:159-70.

12 Stokes EJ, Ridway GL. Clinical bacteriology. 6th edn London: Edward Arnold, 1987:204-22.

13 Chastre J, Fagon JY, Domart Y, Gibert C. Diagnosis of nosocomial pneumonia in intensive care unit patients. Eur 7 Clin Microbiol Infect Dis 1989;8:35-9.

14 Kurashi NY, Al-Hamdan A, Ibrahim EM, Al-Idrissi HY Al-Bayari TH. Community-acquired acute bacterial and atypical pneumonia in Saudi Arabia. Thorax 1992;47:115-8.

15 Al-Hadramy M. Altahawy ATA, Shaf MS. Acute lowe respiratory tract infections in Jeddah. Saudi Med 1988;9:34-9.

16 Mufson MA, Chang V, Gill V, Wood S, Romansky MJ Chancock RM. The role of viruses, mycoplasma and bacteria in acute pneumonia in civilian adults. $A m$ Epidemiol 1976;86:526-44.

17 Bath JC, Boissard GP, Calder MA, Moffat MA. Pneumonia in hospital practice in Edinburgh. $\mathrm{Br} \mathcal{f}$ Dis Chest 1964;58:1-16.

18 Sullivan RJ Jr, Dowdle WR, Marine WM, Hierholzer JC Adult pneumonia in a general hospital. Arch Intern Med 1972:129:935-42.

19 Veary JM Jr. Hospital-acquired pneumonia. In: Wenzel $\mathrm{RP}$, ed. CRC handbook of hospital-acquired infections. Boca Raton: CRC Press, 1981:341-69.

20 Tobin $M D$, Grenvick $A$. Nosocomial lung infection and its diagnosis. Crit Care Med 1984;12:191-9.
21 Miller RT, Kapusnik JE, Sande MA. The diagnosis and herapy of infections in the intensive care unit. In: Shoemaker WC, ed. Critical care: state of the art. Vol 5. Fullerton, California: Society of Critical Care Medicine, 1984:1-54.

22 Nielsen SL, Roder B, Magnussen P, Engquist A, FrimodtMoller N. Nosocomial pneumonia in an intensive care unit in a Danish university hospital: incidence, mortality and etiology. Scand $\mathcal{F}$ Infect Dis 1992;24:65-70.

23 Berger R, Arango L. Etiologic diagnosis of bacterial nosocomial pneumonia in seriously ill patients. Crit Care Med 1985;13:833-6.

24 Mandelli M, Mosconi P, Langer M, Cigada M. Prevention of nosocomial pneumonia in an intensive care unit. A randomized multicenter clinical trial. Crit Care Med 1989;17:501-5.

25 Mock CN, Burchard KW, Asan F, Reed M. Surgical intensive care unit pneumonia. Surgery 1988;104:494-9.

26 Garibaldi RA. Epidemiology of community-acquired respiratory tract infections in adults: incidence, etiology, impact. Am F Med 1985;78:32-7.

27 Niederman MS, Fein AM. Acute infectious pneumonia. In: Rippe JM, Irwin RS, Alpert JS, Fink MP, eds. Intensive care medicine. Boston: Little, Brown, 1991:713-29.

28 Mohamed ARE, Price-Evans DA. The spectrum of pneumonia in 1983 at Riyadh Armed Forces Hospital. F Infect monia in 1983

29 Sorensen J, Forsberg P, Hakanson E, Maller R, Sederholm $\mathrm{C}$, Soren $\mathrm{L}$, et al. A new diagnostic approach to the patient with severe pneumonia. Scand $\mathcal{F}$ Infect Dis 1989;21:33-41.

30 Sorensen J, Cederholm I, Carlsson C. Pneumonia: a deadly disease despite intensive care treatment. Scand $\mathcal{F}$ Infect Dis 1986;18:329-35.

31 Wimberley NW, Bass JB, Boyd BW, Kirkpatrick MB, Serio RA, Pollock HM. Use of a bronchoscopic protected catheter brush for the diagnosis of pulmonary infections. Chest 1982;81:556-62.

32 Villers D, Derriennic $M$, Raffi F, Germaud P, Nicolas F Courtieu AL. Reliability of the bronchoscopic protected catheter brush in intubated and ventilated patients. Chest catheter brush in

33 Woodhead MA. Management of pneumonia. Respir Med 1992;86:459-69.

34 Karalus NC, Cursons RT, Leng RA, Mahood CB, Rothwell RPG, Hancock B, et al. Community-acquired pneumonia: aetiology and prognostic index evaluation. Thorax 1991;46:413-8. 